\title{
Possibility of Detecting Visual Functional Disturbance in Rats by the Open-field Test
}

\author{
Iwami KIYOSAWA, Makoto AOKI, Takahiro IMAMURA, Jun NAITO, \\ Toru R. SAITO*, and Kazuaki W. TAKAHASHI* \\ Kissei Pharmaceutical Co., Ltd., 2,320-1 Maki, Hotaka, Minamiazumi, Nagano 399-83 \\ and ${ }^{*}$ Department of Laboratory Animal Science, Nippon Veterinary and Animal \\ Science University, 1-7-1 Kyonan-cho, Musashino-shi, Tokyo 180, Japan
}

(Received 28 August 1992/Accepted 20 January 1993)

\begin{abstract}
In order to determine whether visual disturbance in small rodents is detectable by means of the open-field test, the ambulation scores of enucleated and intact rats in an open-field were measured. In a 30-min test of Slc:Wistar/ST rats, there were significant differences in ambulation scores between enucleated and intact rats in the first 10-min. In addition, the effects of observation times (09:00-11:00, 13:00-15:00 and 17:00-19:00 hr) and strains on the open-field test were studied using a 10-min test. Regardless of observation times, ambulation scores of enucleated rats of the Slc:Wistar/ST and F344/N Slc strains were significantly elevated as compared with those of intact rats from both strains. When tested during the 13:00-15:00 hr period, there were significant differences in the Slc:SD rats. These findings indicate that the changes in ambulation are due to visual disturbance. However, significant ambulatory changes in F344/N Slc rats were documented at the three different observation times. Based on these results, Slc:Wistar/ST rats appear to be suitable for detecting visual disturbance by the open-field test.-KEY WORDS : ambulation scores, open-field test, rat, time point, visual function
\end{abstract}

\section{オープンフィールド試験による視覚障害ラット 検出の可能性}

\author{
清澤岩水・青木 誠・今村卓広・内藤惇 \\ 斎藤徽*・高橋和 明* \\ キッセイ薬品工業株式会社 \\ *日本獣医畜産大学実験動物学教室
}

近年, 薬物の開発に際し, 薬物の副作用としての視 覚機能障害に関する検討が必要となっている。視覚器 はその構造, 機能の特異性から薬物の副作用を受けや すく，その副作用も不可逆性で重篤な障害であること が知られている。そのため, 薬物の安全性試験の中で 視覚機能検査はその重要度を増し, 各種実験用動物の 視賞機能検查法が検討され, 視覚誘発電位および網膜 電困の測定等が行われている $[7]$ 。しかし,これら の検査は手技が複雑で高価格な測定機器を使用するゆ
えに安全性試験において必ずしもルーチンに赛施され ることは容易ではない。大沼ら [4] はオープンフィ ールド試験 [2] において眼球摘出マウス, 視覚障害 マウスが正常マウスより高い歩行移動量を示すことを 報告している。著者らはオープンフィールド試験に て, Wistar 系, SD系およびF344系ラットの歩行移 動量を検討し, 梘覚機能検査に使用できる可能性を認 めたので報告する。 


\section{材料および方法}

供試動物および飼育環境：供試動物として日本エス エルシー株式会社より入手したSlc:Wistar/ST 系 (以後 Wistar/ST 系と略す), Slc:SD 系 (以後 SD 系) および F344/N Slc 系 (以後 Fischer 系) の雄ラ ット各44匹を 8 週秢にて入手した。各系統ラットとも 10週㱓時に無処置群（対照群）と眼球摘出処置群（摘 出群) の 2 群に分け, 摘出群の動物はペントバルビ夕 ールソーダ (ネンブタール：大日本製楽）深麻酔下に て眼球を摘出し，眼窩に抗生物質を塗布し， 2 週間飼 育した後実験に供した。実験開始時の体重は Wistar/ ST 系344.7 387.9 g, SD 系385.3〜 422.6g, Fischer 系252.9 289.1 g であった。動物は室温22.5〜 $23.7^{\circ} \mathrm{C}$, 湿度 $45.0 \sim 52.9 \%$, 換 気回数 16.7 回/時間 (オールフレッシュエアー方式), 白色蛍光灯による 人工照明12時間（午前 8 時点灯，午後 8 時消灯）の飼 育室のクリーンラック内にて, 洗浄隇菌済ステンレス 製群飼育ケージ $(260 \mathrm{~W} \times 380 \mathrm{D} \times 180 \mathrm{Hmm}$ : 夏目製作 所）に5〜 6 匹ずつ飼育した。飼料として，放射線減 菌固型飼料 $(\mathrm{CE}-2$ : 日本クレア, $10 \mathrm{KGy})$ を, 飲料 水としてフィルター滤過ならびに紫外線照射処理した 水道水を自動給水器 $(\mathrm{TV}-15$ : システムエンジニア リング）にてそれぞれ自由攝取させた。

オープンフィールド試験による歩行移動量の測定： 使用したオープンフィールドをFig. 1 に示した。フ イールドは幅 $2 \mathrm{~mm} の$ 黒線で $20 \times 20 \mathrm{~cm}$ の 6 区画に分 割した $40 \times 60 \mathrm{~cm}$ の灰色のステンレス製トレーを使用 し, 四方を高さ $40 \mathrm{~cm}$, 厚さ $4 \mathrm{~mm}$ の白色アクリル板 で囲った。装置はフィールドが営光灯の直下で天井よ り $180 \mathrm{~cm}$, 床より $70 \mathrm{~cm}$ になるように飼育室の一定位 置に設置された。測定時の照度はフィールド中央部で 480Lux, コーナーで310 450Lux であった。背景音 レベルは $57.5 \mathrm{~dB}$ (クリーンラックより発する単一 音)であり, 飼育室内の臭気 (アンモニア濃度) は 1 $\mathrm{ppm}$ 末満であった。ラットの腹部を手で抱えてケー ジより取り出し, Fig.1のA区画でラットの頭部をb コーナーに向けて置き, 測定を開始した。矢印方向よ り装置から $30 \mathrm{~cm}$ 離れた斜め上方より観察を実施し た。ラットが区画線を横断する時, 区画線の交点を越 える時, 区画線上を移動する時に体長部（鼻端部から 尾根部まで) が通過すれば歩行移動量を『1』とし た。測定の終了したラットはすみやかにケージに戻

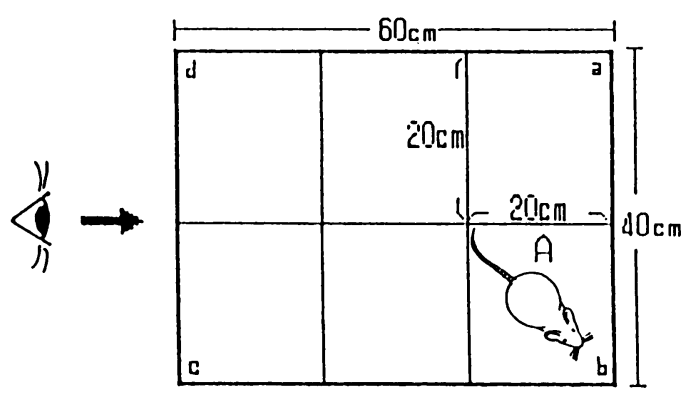

Fig.1. Schematic representation of open-field apparatus

し， 1 個体の測定が終了するごとに囲いの内面を酒精 綿で清拭し，フィールドは洗浄滅菌済のものと交換し た。

実験 I . 観察時間帯における歩行移動量の検討： Wistar/ST 系を用いて, $9 \sim 11$ 時, 13〜15時および 17〜 19時の各 2 時間の時間帯内の30分間において, 10 分単位の歩行移動量を測定した。なお，観察時間帯は 飼育管理, 各種検査の作業時間を考虑して設定した。

実験 II. 観察時間帯における歩行移動量の系統差の 検討：実験 I の結果，10分間の観察にて歩行移動量の 差を検討できる事が明らかとなったので, Wistar/ ST 系, SD 系および Fischer 系を用いて, 実験 1 と 同時間帯で歩行移動量を10分間ずつ測定した。なお, Wistar/ST 系の 1 回目の成績は実験 1 の成績を使用 した。測定に供する個体の順番および観察時間帯はラ ンタムに分散させた。

統計処理：各群の平均値および標準誤差を算出し, 各群間の平均値の差が $\mathrm{F}$ 検定により等分散ならば Student- $\mathrm{t}$ 検定を，不等分散ならば Mann-Whitney U 検定を用いて解析した。

\section{成}

1. 観察時間帯におけるWistar/ST 系ラットの歩行 移動量 (実験 I )

10分間単位の歩行移動量の变化を Fig.2に示した。

$9 \sim 11$ 時に観察された 30 分間の平均歩行移動量 $( \pm$ 標準誤差) は摘出群 $74.2 \pm 4.3$, 对照群 $49.7 \pm 4.8$ であ り, 摘出群が有意に高い值を示した $(\mathrm{P}<0.01)$ 。観察 開始から 10 分間では摘出群 $40.9 \pm 2.3$, 对照群 $31.2 \pm$ 2.7 で，30分間全体に対し摘出群は $55.1 \%$, 対照群は $62.7 \%$ 占めていた。10 20分間での歩行移動量は摘 出群19.2 1.6 , 対照群 $12.4 \pm 1.5$ であり, $20 \sim 30$ 分 

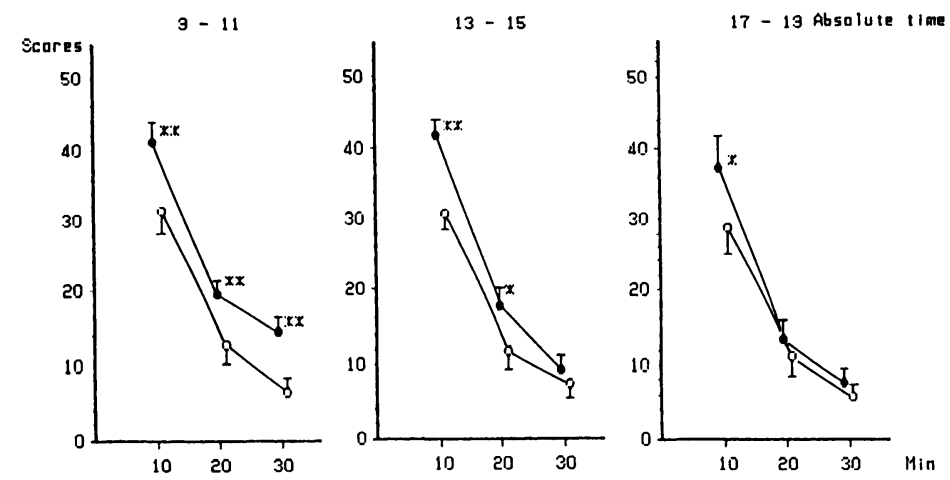

Fig.2. Time-related changes in ambulation during 30-min examination period in Wistar/ST rats $\bullet$ Enucleated rats $(n=21) \quad \circ$ Intact rats $(\mathrm{n}=21) \quad$ Mean \pm S.E.

$*$ : Significant difference from intact rats : $\mathrm{P}<0.05$

**: Significant difference from intact rats $: \mathrm{P}<0.01$

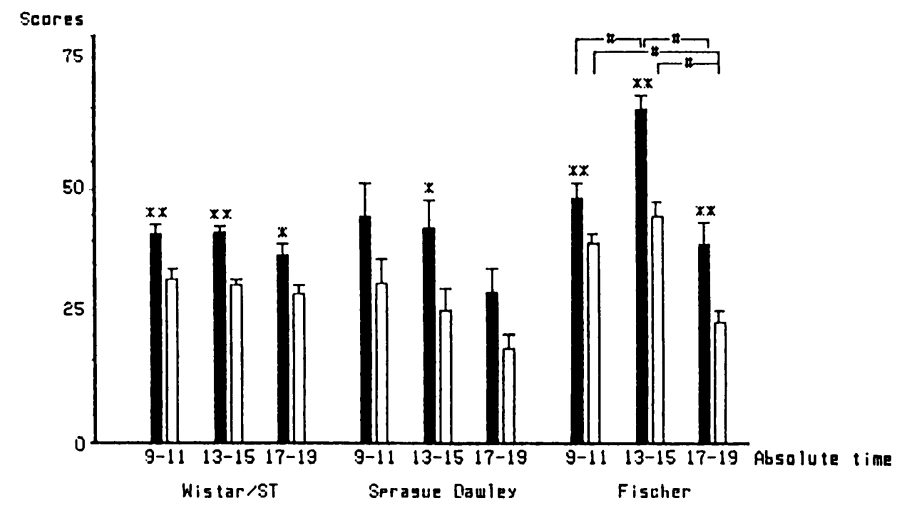

Fig:3. Ambulation scores during 10-min examination period in three different strains of rats $\square$ Enucleated rats $(\mathrm{n}=21) \quad \square$ Intact rats $(\mathrm{n}=21) \quad$ Mean \pm S.E.

* : Significant difference from intact rats : $\mathrm{P}<0.05$

** : Significant diffrence from intact rats $: \mathrm{P}<0.01$

$\#: \mathrm{P}<0.01$

間での歩行移動量は摘出群 $14.1 \pm 1.5$, 対照群 $6.1 \pm$ 1.4であった。10分毎の両群の歩行移動量を比較する と, いずれの 10 分間でも摘出群が対照群より有意に高 かった $(\mathrm{P}<0.01)$ 。

13〜15時に観察された30分間の歩行移動量は摘出群 $67.4 \pm 3.9$, 対照群 $48.8 \pm 3.1$ であり, 摘出群が有意に 高い值を示した $(\mathrm{P}<0.01)$ 。観察開始から10分間では 摘出群 $41.4 \pm 1.7$, 对照群 $30.3 \pm 1.7$ で, 30分間全体に 対して摘出群 $61.4 \%$, 对照群 $62.0 \%$ を占めていた。 10 20分間での歩行移動量は摘出群 $17.2 \pm 2.0$, 对照

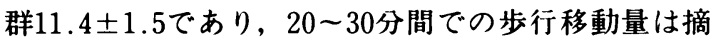

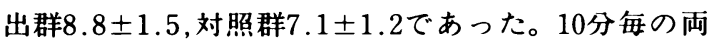

群の歩行移動量を比較すると, 観察開始から10分間お よび10 20分間において摘出群が対照群より有意に高 く $(\mathrm{P}<0.05,0.01), 20$ 30分間では有意差はみられ なかった。

17〜19時に観察された 30 分間の歩行移動量は摘出群 $57.2 \pm 4.1$, 対照群 $44.5 \pm 3.2$ で有意差が認められた $(\mathrm{P}<0.01)$ 。観察開始から10分間では摘出群 $37.0 \pm$ 2.9 , 対照群 $28.1 \pm 2.2$ で, 30 分間全体に対し摘出群 $64.8 \%$ ，対照群 $63.0 \%$ を占めていた。10２0分間での 歩行移動量は摘出群 $13.0 \pm 1.3$, 対照群 $11.2 \pm 1.7$ であ ク, 20 - 30分間での歩行移動量は摘出群 $7.2 \pm 1.1$, 対 照群5.2 1 1.1であった。10分毎の両群の歩行移動量を 
比較すると, 観察開始から10分間のみ摘出群が対照群 より有意に高く $(\mathrm{P}<0.05), 10 ２ 0 ， 20 \sim 30$ 分間では 有意差は見られなかった。

2. 観察時間帯における步行移動量の系統差（実験 II)

実験 Iの結果より，10分間の観察により歩行運動量 の差を検討できることが明らかとなったので，Wis$\operatorname{tar} / \mathrm{ST}$ 系, SD 系および Fischer 系各ラットの各観 察時間帯での観察開始から10分間の歩行移動量を Fig.3に示した。なお, Wistar/ST 系については, 実 験 Iの成績を使用した。

前述したごとくWistar/ST 系ラットでは測定開始 から10分間に，いずれの時間帯でも摘出群は対照群よ り有意に高い歩行移動量を示した $(\mathrm{P}<0.05,0.01)$ 。 摘出群, 対照群での各時間帯間の歩行移動量を比較し た結果，いずれも有意差は認められなかった。

$\mathrm{SD}$ 系ラットでは 9 〜11時の観察は摘出群44.6土 6.5, 対照群 $30.5 \pm 5.2,13 \sim 15$ 時の観察では摘出群 $42.0 \pm 5.4$, 対照群 $24.7 \pm 4.6,17 \sim 19$ 時の観察では摘 出群 $28.3 \pm 5.6$, 対照群 $16.9 \pm 3.0$ であった。13 15時 では摘出群は対照群より有意に高い歩行移動量を示し た $(\mathrm{P}<0.05)$ 。 9 11時, 17 19時では, 摘出群が対 照群より高い步行移動量を示す傾向が観察されたが, 有意差は認められなかった。摘出群, 对照群内で歩行 移動量を比較した結果, 両群とも17 19時に減少傾向 が認められたのみで有意差は見出せなかった。

Fischer 系ラットでは 9 11時の観察は摘出群

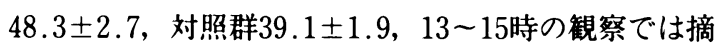

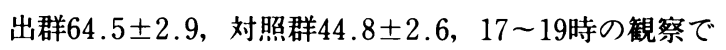
は摘出群 $38.7 \pm 4.2$, 対照群 $22.1 \pm 2.5$ であり, すべて の時間帯で摘出群は对照群より有意に高い歩行移動量 を示した $(\mathrm{P}<0.01)$ 。各時間帯間の比較では摘出群 で，13〜15時が 9 11，17～19時より有意に高い歩行 移動量を示し $(\mathrm{P}<0.01)$, 対照群では 9 11時, 13〜15時が17〜19時より有意に高い歩行移動量を示し た $(\mathrm{P}<0.01)$ 。

\section{考察}

歩行移動，たちあがり等の自発運動はラットの生得 的行動として代表的なものであり，観察が容易である ことから，行動観察の対象とされている。また，薬物 の効果や副作用をラット，マウス等の自発運動を指標 として検討する際, 一般的にオープンフィールド試験
による行動観察が行われている。著者らは薬物の副作 用として視覚障害が発生した際のラットの行動の特性 を検討するため, 眼球摘出ラットと無処置ラットのオ ープンフィールドでの歩行移動量を検討した。

歩行移動をオープンフィールドでの新奇環境への適 応のための探索行動 [1］として捕らえてみると，ラ ットの歩行移動量は摘出群, 対照群ともに観察開始か ら10分間に集中し，その後は急激に減少した。このこと から, 観察を10分間に設定すれば対照群との步行移動量 の差も大きく, 立ち上がり等の歩行移動以外の自発運動 も少なく，視覚障害を検出し得ると思われた。

しかし，このラットの歩行移動量を詳細に調べる と, 系統差が認められた。Wistar/ST 系ラットでは いずれの時間帯でも摘出群は対照群より高い步行移動 量を示し, 両群内で各時間帯の絶対值を比較してもほ ほ一定で, 時間帯に関係なく視覚障害検出が可能と思 われた。SD系ラットは摘出群, 対照群ともに個体間 のばらつきが大きいため13 15時の観察のみ視覚障害 が検出可能であった。Fischer 系ラットはいずれの時 間帯でも摘出群は対照群より有意に高い歩行移動量を 示し, 視覚障害の検出が可能であったが, 時間帯によ つて歩行移動量が異なることを考虑しておく必要性が 示唆された。

今回のオープンフィールド試験の結果, 10分間にわ たる 1 回の歩行移動量の測定で有意な差が確認できた が, オープンフィールド試験の信頼性を検討する方法 として同一個体を反復して同一試験に用いて検査の安 定性をあらわす再テスト法 [6] も検討されている。 さらに，オープンフィールド試験は実験条件の設定も 信頼性の大きな要因となる $[8,9]$ と言われてい る。今回, 反復試験により信頼性の検討は実施しなか つたが，充分な有意差が確認でき，実験条件の設定も 充分であったと思われる。

恒明あるいは恒暗条件下では, 動物の行動活性リズ ムはフリーランし，ついには固有の周期をとる [5] といわれる。また, Gobら［3]は, 生後 7 日目に て眼球摘出したラットを術後10日から30日目までオー プンフィールド試験を実施し，すべての試験日で眼球 摘出ラットに有意な增加を認めた $(\mathrm{P}<0.01)$ と報告 している。これらの報告より, 眼球摘出によりラット の行動活性リズムはフリーランするが, 眼球摘出後 2 週間程の今回のような時期に塞施されるオープンフィ ールド試験には影響ないものと考えられた。以上よ り, 10分間の 1 回施行によるオープンフィールド試験 
により視覚機能障害の検出が可能であり, 今回検討し た 3 系統では Wistar/ST 系ラットを使用することが 最適であると結論された。

\section{要 約}

オープンフィールド試験で眼球摘出ラットおよび無 処置ラットの歩行移動量を比較し, 同試験による視賞 機能障害検出の可能性を検討した。Slc:Wistar/ST 系ラットを用いて30分間測定した結果, 10分間の観察 で無処置群との間に有意差が認められた。次に, 観察 に適した系統と時間帯を検討するために, Slc:Wis$\operatorname{tar} / \mathrm{ST}$ 系, Slc:SD 系および F344/N Slc 系ラットを 用いて 9 11時, 13〜15時および17〜19時の時間帯に 10分間の測定を実施した。その結果, Slc:Wistar/ST 系および F344/N Slc 系ラットではすべての時間帯 に, Slc:SD 系ラットでは13〜15時に無処置群との間 に有意差が認められ, 視覚障害による歩行移動量の変 化が確認された。しかし，F344/N Slc 系ラットでは 時間帯により歩行移動量に有意な差があることが確認 された。以上より，オープンフィールド試験にて視覚
機能を検討する場合, 3 系統の中では Slc:Wistar/ ST 系ラットを用いることが最適であると考えられ た。

\section{文献}

[1] 藤田 統 (1967). 生体が受容する刺激の意味について (その 1). 東京教育大学教育学部紀要, 13，85-97.

[2]福原武彦・小野 宏〔編集〕(1990). 毒性試験講座 7 . 機能 毒性学.pp.22-23, 地人書館, 東京.

[3] Gob, R., Kollner, U., Kollner, O., and Klingberg, F. (1987). The post natal development of open field behaviour of the visually deprived rat. Biomed. Bio. chim. Acta., 4, 215-223.

４４］大沼富雄・赤堀 修・斉藤 徹・高橋和明（1980）。簡易な 自発運動量 5 分間測定法による視覚障害マウス検出の可 能性について. 実験動物技術, 2, 101-104.

[5]篠田元扶・田所作太郎 (1989). サーカディアンリズムー昼 と夜の違い一。臨床麻䣲, 10,1381-1387.

[6] 霫敏明 (1983). Open-field test の妥当性と信頼性. 先 天異常, 23, 131-135.

[ 7 ] 高橋和明・天尾弘実・鈴木勝士・ 今道友則 (1982). 各種実 験用動の視 - 聴覚器検査法. 昭和 57 年度科学研究費補助金 (一般研究B) 研究成果報告書, 8-88.

[8] Tanaka, K. (1983). Determining of operating condition for the open fieldtest under nonclinical fertility study. Cong. Anom. 23, 145-155.

[9] 吉田順一一小佐妻恒夫 $(1983)$. オープンフィールド試験に おける実験条件の検討. 先天異常, 23, 157-164. 